Marijana Joksimović ${ }^{1}$

College of Academic Studies “Dositej”, Belgrade

Dušan Joksimović ${ }^{2}$

University of Criminal Investigation and Police Studies,

Belgrade

Biljana Grujić Vučkovski ${ }^{3}$

Institute of Agricultural Economics, Belgrade
ORIGINAL SCIENTIFIC ARTICLE

doi: 10.5937/ekonomika2002049J

Received: March, 25. 2020.

Accepted: April, 24. 2020.

\title{
A TEST OF INTERNATIONAL FISHER EFFECT: RESEARCHING FROM SERBIA AND THE EUROPEAN UNION ${ }^{4}$
}

\begin{abstract}
The aim of this paper is to explore the International Fisher Effect (IFE) between Serbia and European Union (EU) in period between 2004 and 2015. The authors in this paper explore the IFE by applying regression analysis. They were used historical annual data for exchange rates, real interest rate and inflation, in this research. Like a home country and foreign country the authors were used each of these areas (Serbia and EU) like interchangeably and track the trail of the effect. Explore was based on the time series of observed annual data in period between 2004 and 2015. The authors were used the data of authorized central banks from databases: the World Bank, the National Bank of Serbia and the European Central Bank. Regression analysis was performed using a software package SPSS 20. The contribution of this paper is reflected in the obtained results. The results show that a $1 \%$ increase in the nominal interest rate differential, on average, lead to approximately a $0.3 \%$ offsetting change in the exchange rate in both cases (Serbiahome EU-foreign and EU-home Serbia-foreign). The coefficients of determination $R^{2}$ are very low, also in both cases. Only 3.3\% of the annual changes in the RSD/EUR exchange rate and $4.2 \%$ of the annual changes in the EUR/RSD exchange rate can be explained by the nominal interest differentials. Therefore, about $96 \%$ of the annual changes in the exchange rates depend on other factors.
\end{abstract}

Key words: IFE (International Fisher Effect), Inflation, Interest Rates, Exchange Rates, Regression Analysis, Serbia and European Union.

JEL classification: C00, E43

\footnotetext{
1 joksimovicmarijana80@gmail.com; ORCID ID 0000-0002-5939-5137

2 dusan.joksimovic@kpu.edu.rs; ORCID ID 0000-0001-7972-1991

${ }^{3}$ biljana_g@iep.bg.ac.rs; ORCID ID 0000-0003-2588-4888

${ }^{4}$ Paper was financed by the Ministry of Education, Science and Technological Development of the Republic of Serbia.
} 


\title{
ТЕСТ МЕЪУНАРОДНОГ ФИШЕРОВОГ ЕФЕКТА: ИСТРАЖИВАЫЕ ИЗ СРБИЈЕ И ЕВРОПСКЕ УНИЈЕ
}

\begin{abstract}
Апстракт
Циљ овог рада је истраживање Међународног Фишеровог ефекта (IFE) између Србије и Европске уније у периоду 2004-2015 године. Аутори у овом раду IFE истражују регресионом анализом. Користили су се историјски подаци курса РДС и ЕУР, реалне каматне стопе и инфлаичје посматраних земаља. Свака од поменутих земаља (Србија и ЕУ) су се наизменично користилие као матична и страна земьа. Истражсиване се заснивало на временским серијама посматраних података од 2004. до 2015. године. Коришћени су подаци овлашћених иентралних банака из база: Светске банке, Народне банке Србије и Европске централне Банке. Регресиона анализа извршена је помоћу програмског пакета СПСС 20. Допринос овог рада се огледа у добијеним резултатима. Резултати показују да раст номиналне каматне стопе од 1\%, у просеку, доводи до промене девизног курса за око 0,3\% у оба случаја (Србија - ЕУ и ЕУ - Србија). Коефичијент детерминачије Р2 је веома мали, такође у оба случаја. Само $3.3 \%$ годишье промене курса РСД/ЕУР u 4.2\% годишье промене курса ЕУР/РСД може бити објашњено променом номиналне каматне стопе. Око 96\% годишње промене курса зависи од других фактора.
\end{abstract}

Кључне речи: IFE (Међународни Фишеров ефекат ), инфлација, каматне стопе, девизни курсеви, регресиона анализа, Србија и ЕУ

\section{Introduction}

Stable financial institutions are necessary for the country's economy to develop. Accordingly, banks play an extremely important role in this process because economic growth requires an efficient banking sector that would provide macroeconomic stability (Muhović, Subić, 2019). The authors (Ercegovac et al., 2019) state that the banking sector is the most significant segment of the financial system of any modern and developed economy. As such, it enables the entire economic system to function undisturbed, contributing to sustainable economic growth and development. Serbia is obliged to adjust its legal framework with other EU members (Grujić, Joksimović, 2019).

The International Fisher Effect (IFE) theory suggests that foreign currencies with relatively high nominal interest rates will tend to depreciate because higher nominal interest rates reflect expected rate of inflation (Korab, Svatopluk, 2013; Anokye, Ofori, 2017; El Khawaga et. al., 2013; Ucak et. al., 2014; Uyaebo et. al., 2016; He, 2018).

In this paper, regression results for empirical testing of IFE showed that nominal interest rate differentials had positive but no significant effect on changes in exchange rate between Serbia and EU. The authors have already applied regression analysis to their earlier research (Joksimovic et. al., 2018) and analyzed money markets (Kaludjerovic et. al., 2016).

The relationship between nominal interest rates and expected inflation is crucial in the global financial markets. The International Fisher Effect has suggested that nominal interest rates and expected inflation move together, as one follows the other (Shalishali, Maurice, 2012). 
A regression analysis of IFE was applied to historical annual data for exchange rates, real interest rate and inflation for Serbia and EU, in period between 2004 and 2015. Like a home country and foreign country we used each of these areas like interchangeably and track the trail of the effect.

Depreciation of currency prices is directly related to differences in nominal interest rates. The IFE theory is a key link in the field of economics and finance that connects real interest rates, inflation, respectively nominal interest rates and exchange rates. This theory is a combination of two theories: the generalized version of the Fisher effect theory (GFE) and the relative version of the Purchasing Power Parity theory (PPP).

The generalized version of the Fisher effect theory states that if the real interest rate is equal between different countries, it follows that the differences in their observed nominal interest rates must arise from differences in expected inflation.

The relative version of the PPP theory implies that inflation differential will be offset by exchange rate changes.

In the short term, the IFE theory proved unreliable due to various short-term factors that directly affect exchange rates and predictions of nominal rates and inflation. On the other hand, the long-term international effects of IFE have proved to be better, but not much. Foreign exchange rate courses compensate for interest rate differences, but forecasting errors often arise when the goal is to try to predict the spot rate in the future. This is in line with Maduro's, (Madura, 2010) claim that the IFE theory does not indicate that the relationship will exist at any time, but periodic investments that try to capitalize at a higher interest rate would achieve a similar yield on average that they were simply made in the domestic market and periodically.

\section{Previous research}

The last years, many authors were explored IFE theory in between different areas.

Anokye and Ofori (2017) investigated the validity of the International Fisher Effect in the West African Monetary Zone (WAMZ). The conventional Engle-Granger and fractional cointegration tests were employed on nominal exchange differentials and exchange rates change of all the countries within the WAMZ except Liberia due to lack of data. They observed cointegrating relationship in fifteen out of the twenty country pairs; indicating evidence of common stochastic drift in nominal exchange differentials and exchange rates change.

Bayat et. al. (2018) investigated the relation between consumer price index and policy interest rate variables in Brazil, India, Indonesia, South Africa and Turkey in the context of Fisher hypothesis in the period between January 2000 and January 2016. In the initial finding of the empirical analysis, they find cross - sectional dependence between the countries.

Authors El Khawaga et. al. (2013) examined the validity of the International Fisher Effect (IFE) theory for the Egyptian economy. Two case studies are investigated: Egypt vs. USA and Egypt vs. Germany during the period 2003-2012. The empirical findings revealed partial significance of IFE in the case of Egyptian pound vs. US dollars, while no sign of IFE was detected in the case of Egyptian pound vs. Euro currency. The irrelevance of IFE could be attributed to the irrelevance of Purchasing Power Parity theory in Egypt. This is in addition to Egypt's limited financial integration with international financial markets. 
Author He (2018) investigated the Fisher effect and the international Fisher effect between China and South Korea in the long and short run, respectively. The results exhibit whenever in the long or short run, the Fisher effect exists in China and South Korea. However, the Fisher effect in South Korea is more significant than that of in China. This result also certifies that the South Korea's marketization of the economy is higher than that of China's.

Korab and Svatopluk (2013) studied the behavior of inflation rate, short-term interest rate and nominal exchange rate after leaving fixed exchange rate arrangement and move to floating. They found that countries with rigid exchange rate policy, less frequently adjusted central parity and narrow exchange rate bands experienced sharp depreciation after leaving peg, but the depreciation was only temporary with no long trend. In this group of countries the exchange rate adjustment is weakly exogenous to inflation and interest rate differentials and the theory of International Fisher Effect was not mostly confirmed. On the contrary, countries with flexibly adjusted central parity and wider exchange rate bands did not experience rapid depreciation.

In the paper from authors Machobani et. al. (2017) the International Fisher Effect (IFE) were tested in the context of South Africa as an emerging economy. The results from the International Fisher Effect were predominantly insignificant, though there seems to be some moderate evidence in support of the International Fisher Effect for the case of the South Africa-EUR. The R-squares were found to be low, suggesting the exchange rate is instead explained by many other factors, not just the changes in nominal and real interest rates and the rate of inflation.

Nchor and Darkwah (2015) investigated the impact of exchange rate movement and the nominal interest rate on inflation in Ghana. They also looked at the presence of the Fisher Effect and the International Fisher Effect scenarios. Ordinary Least Squares regression methods were employed to determine the presence of the Fischer Effect and the International Fisher Effect. The results from the study show that in the short run a percentage point increase in the level of depreciation of the Ghana cedi leads to an increase in the rate of inflation by $0.20 \%$. A percentage point increase in the level of nominal interest rates however results in a decrease in inflation by $0.98 \%$. Inflation increases by $1.33 \%$ for every percentage point increase in the nominal interest rate in the long run. An increase in inflation on the other hand increases the nominal interest rate by $0.51 \%$ which demonstrates the partial Fisher effect. A $1 \%$ increase in the interest rate diff erential leads to a depreciation of the Ghana cedi by approximately $1 \%$ which indicates the full International Fisher effect.

In the paper (Shalishali, 2012), in a statistical test of the IFE, a regression analysis was applied to historical exchange rates and interest differentials data for eight selected Asian countries namely: China, India, Japan, South Korea, Malaysia, Thailand, Vietnam, and Indonesia. Each of these countries was used interchangeably as the home country, and foreign country so as to investigate the direction of the parity. The results are mixed. While the theory holds for some countries, it does not hold for others. The theory holds when some countries were used as home country but was refuted when they were used as foreign countries. This suggests that there may be some impediments to foreign trade that may affect exchange rate adjustment apart from interest and inflation rates differentials.

Ucak et. al. (2014) investigated the Fisher effect in four EU member states: Czech Republic, Hungary, Poland and Slovak Republic. They applied the new bootstrap 
method. The result of this study shows that Fisher effect for selected EU member states are more than one. This value might be explained by the agreement regarding taxation of the interest income.

Uyaebo et all. (2016) tested the validity of the Fisher hypothesis in Nigeria during the period 1970 - 2014. The Gregory and Hansen Co-integration test confirmed the existence of a long-run relationship between nominal interest rates and inflation, albeit with a structural break in October 2005. The obtained Fisher coefficient in the cointegrating relation was 0.08 , implying a weak form of Fisher effect in the long-run. On the basis of these findings, they upheld a weak Fisher effect in the long-run and nonexistence of Fisher effect in the short-run. This implied that short term nominal interest rate is a good characterization of monetary policy stance. Also, the obtained partial Fisher effect indicated that changes in monetary policy are capable of altering the long term real interest rate and influencing economic growth through the interest rate channel.

The main purpose of study Varamini et. al. (2017) is to examine if the International Fisher Effect holds between Mexico and the United States for the period from Q1: 2005 through Q3: 2016. The results of this study indicate a significant relationship between the interest rate differentials and the changes in the currency value between the two countries. The regression model suggest that the independent variable, change in interest rate differential, has a correlation to change in exchange rates over the period observed. Even though the result of this study provides some support in favor of the International Fisher effect, the low value of the R-squared would suggest there are other left-out variables that have an effect on change in exchange rates between the two countries. These variables could be inflation, confidence in the currencies, expectations, currency risk, transaction costs, current account on balance of payments and economic growth, among others. Despite the existence of such factors that could positively and negatively affect the changes in exchange rate between the United States and Mexico, the change in interest rate differential must be included as an important determinant of the currency value.

\section{Methodology and data collection}

Like we said IFE is a combination of two theories: the generalized version of the Fisher effect theory (GFE) and the relative version of the Purchasing Power Parity theory (PPP).

The Fisher effect theory states that the nominal interest rate $\left(r_{n}\right)$ in a country is determined by the real interest rate $\left(r_{r}\right)$ and by expected inflation rate $(E(i))$ as follows: $1+r_{n}=\left(1+r_{r}\right)(1+E(i))$

So, if we analyze two countries, home (index $h$ ) and foreign (index $f$ ) country, we have

$$
\begin{aligned}
& 1+r_{n, h}=\left(1+r_{r, h}\right)\left(1+E(i)_{h}\right) \\
& 1+r_{n, f}=\left(1+r_{r, f}\right)\left(1+E(i)_{f}\right)
\end{aligned}
$$


Divided equation (2) by (3), assume that $r_{r, h}=r_{r, f}$, we obtained the generalized version of the Fisher effect theory (GFE):

$$
\frac{1+r_{n, h}}{1+r_{n, f}}=\frac{1+E(i)_{h}}{1+E(i)_{f}}
$$

The GFE theory states that if the real interest rate is equal between different countries, it follows that the differences in their observed nominal interest rates must arise from differences in expected inflation.

The PPP theory states that the exchange rate between any two countries (in our case between home and foreign country) will adjust to reflect changes in the price levels of the same two countries, as follows:

$$
\frac{S_{t+1}-S_{t}}{S_{t}}=\frac{i_{t, h}-i_{t, f}}{1+i_{t, f}}
$$

where

$S_{t+1}$ is the home currency value of one unit of foreign currency at time $t+1$,

$S_{t}$ is the home value of one unit of foreign currency at time $t$,

$i_{t, h}$ is the inflation rate in the home country at time $t$,

$i_{t, f}$ is the inflation rate in the foreign country at time $t$.

By combining equations (4) and (5), and taking into account that expected inflation rate at time $t$ is inflation rate at time $t,\left(E(i)_{t}=i_{t}\right)$, we obtained IFE relation:

$$
\frac{S_{t+1}-S_{t}}{S_{t}}=\frac{r_{n, h, t}-r_{n, f, t}}{1+r_{n, f, t}}
$$

where

$S_{t+1}$ is the home currency value of one unit of foreign currency at time $t+1$,

$S_{t} \quad$ is the home currency value of one unit of foreign currency at time $t$,

$r_{n, h, t}$ is the nominal interest rate in the home country at time $t$,

$r_{n, f, t}$ is the nominal interest rate in the foreign country at time $t$.

IFE relation shows the dependence changes of exchange rate the home currency value of one unit of foreign currency on the nominal interest rate in the home and foreign country.

If $r_{n, h, t}-r_{n, f, t}>0$ then $S_{t+1}-S_{t}>0$ and we expect an appreciation of the foreign currency.

If $r_{n, h, t}-r_{n, f, t}<0$ then $S_{t+1}-S_{t}<0$ and we expect a deprecation of the foreign currency.

A test IFE by applying linear regression analysis takes the following form:

$$
\frac{s_{t+1}-s_{t}}{s_{t}}=\alpha+\beta \cdot\left(\frac{r_{n, h, t}-r_{n, f, t}}{1+r_{n, f, t}}\right)+\varepsilon_{t+1}
$$


where $\varepsilon_{t+1}$ is error term.

If value $\alpha=0$ and $\beta=1$ are in the $95 \%$ confidence interval for obtained value for $\alpha$ i $\beta$ from linear regression analysis, then that linear regression analysis is not disprove influence IFE between analysed countries.

We were tested IFE by applying linear regression analysis between Serbia and EU, in period between 2004 and 2015 (for currency value between 2004 and 2016). Like a home country and foreign country we used each of these areas like interchangeably. Test was performed using a software package SPSS20.

We used historical annual data for currency value, real interest rate and inflation for Serbia and EU, in period between 2004 and 2015 (for currency value between 2004 and 2016). Values for nominal interest rate $r_{n}$, we obtained from equation (1), with approximation $r_{r} \cdot E(i) \cong 0$, as follows:

$$
\begin{aligned}
& 1+r_{n}=\left(1+r_{r}\right)(1+E(i))=1+r_{r}+E(i)+r_{r} \cdot E(i) \cong 1+r_{r}+E(i) \Rightarrow \\
& r_{n}=r_{r}+E(i) .
\end{aligned}
$$

Taking into account that expected inflation rate at time $t$ is inflation rate at time $t$, $\left(E(i)_{t}=i_{t}\right)$, we obtained that at time $t$ nominal interest rate $r_{n, t}$ is equal:

$$
r_{n, t}=r_{r, t}+i_{t}
$$

\begin{tabular}{|c|c|c|c|c|c|c|c|c|}
\hline Year & $\begin{array}{l}\text { Curr. } \\
\text { value } \\
\text { RSD/ } \\
\text { EUR }\end{array}$ & $\begin{array}{l}\text { Curr. value } \\
\text { EUR/RSD }\end{array}$ & $\begin{array}{c}\text { The real int. } \\
\text { rate, } \\
\text { Serbia } \\
(\%)\end{array}$ & $\begin{array}{c}\text { The } \\
\text { inflation } \\
\text { Serbia } \\
(\%)\end{array}$ & $\begin{array}{l}\text { The nom. int. } \\
\text { rate Serbia } \\
(\%)\end{array}$ & $\begin{array}{c}\text { The real } \\
\text { int. rate } \\
\text { EU } \\
(\%)\end{array}$ & $\begin{array}{c}\text { The inflation } \\
\text { EU } \\
(\%)\end{array}$ & $\begin{array}{l}\text { The nom. int. } \\
\text { rate EU(\%) }\end{array}$ \\
\hline 2004 & 72.6937 & .0138 & -5.1640 & 11.0260 & 5.8620 & 3.0000 & 2.1000 & 5.1000 \\
\hline 2005 & 82.9904 & .0120 & -10.3990 & 16.1200 & 5.7210 & 3.1000 & 2.2000 & 5.3000 \\
\hline 2006 & 84.1101 & .0119 & -6.4440 & 11.7240 & 5.2800 & 4.0000 & 2.0000 & 6.0000 \\
\hline 2007 & 79.9640 & .0125 & -3.9640 & 6.3920 & 2.4280 & 4.7500 & 2.5000 & 7.2500 \\
\hline 2008 & 81.4405 & .0123 & -2.7990 & 12.4110 & 9.6120 & 4.0000 & 2.8500 & 6.8500 \\
\hline 2009 & 93.9517 & .0106 & -.9430 & 8.1170 & 7.1740 & 2.2000 & .5000 & 2.7000 \\
\hline 2010 & 103.0431 & .0097 & .8100 & 6.1430 & 6.9530 & 1.7500 & 1.5000 & 3.2500 \\
\hline 2011 & 101.9502 & .0098 & 2.5870 & 11.3370 & 13.9240 & 2.0000 & 2.6500 & 4.6500 \\
\hline 2012 & 113.1277 & .0088 & 3.5630 & 7.3300 & 10.8930 & 1.6000 & 2.4500 & 4.0500 \\
\hline 2013 & 113.1369 & .0088 & 3.9540 & 7.6940 & 11.6480 & 1.1000 & 1.5000 & 2.6000 \\
\hline 2014 & 117.3060 & .0085 & 4.2030 & 2.0820 & 6.2850 & .5000 & .3000 & .8000 \\
\hline 2015 & 120.7328 & .0083 & 3.1300 & 1.3920 & 4.5220 & .3000 & .1000 & .4000 \\
\hline 2016 & 123.1179 & .0081 & - & - & - & - & - & - \\
\hline
\end{tabular}

Tabular and graphical views of the historical annual data used are below.

Table 1: Used historical data

Source: The European Central Bank, The National Bank of Serbia and The World Bank 
Figure 1 (left): The home currency value of one unit of foreign currency Serbia-home, EU-foreign; Figure 2 (right): The home currency value of one unit of foreign currency EU-home, Serbia-foreign
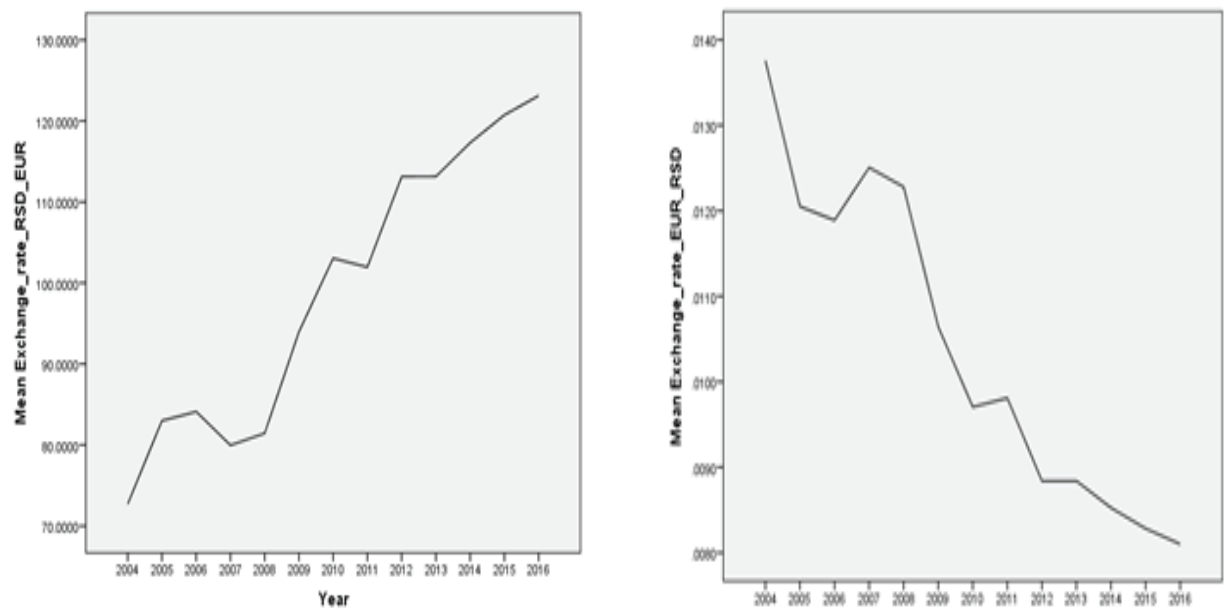

Source: National Bank of Serbia (NBS)

Figure 3 (left): The real interest rate Serbia; Figure 4 (right): The inflation Serbia
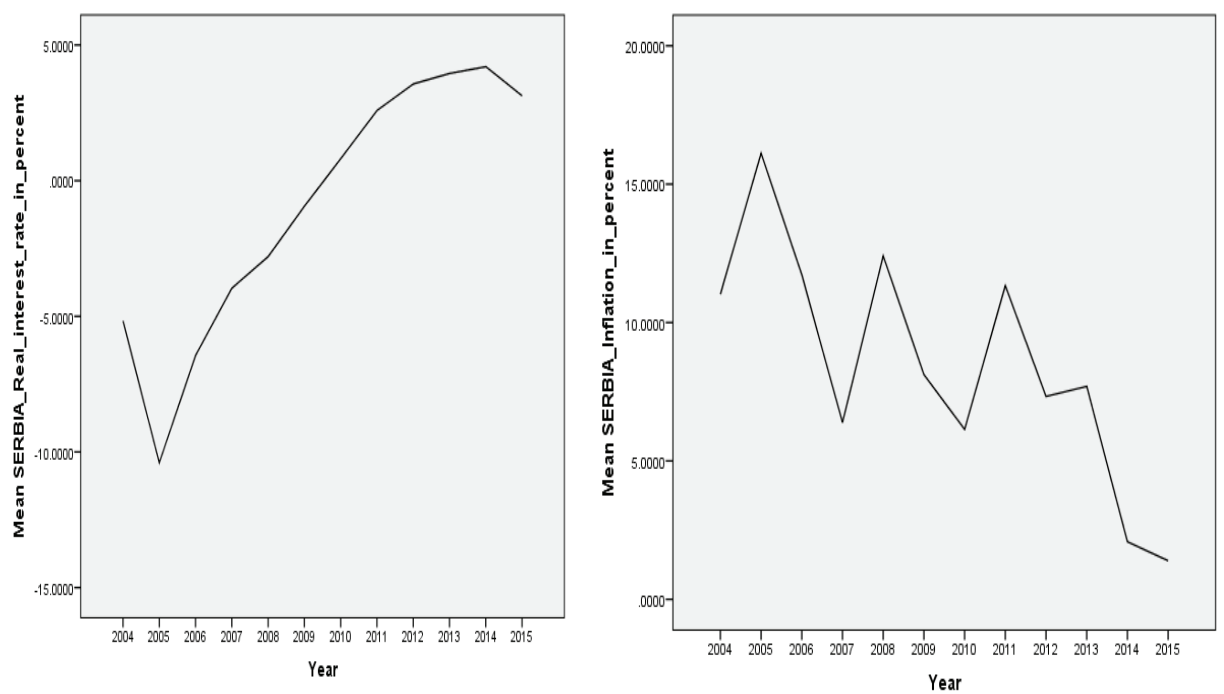

Source: The World Bank Group 
Figure 5 (left): The nominal interest rate Serbia; Figure 6(right): The real interest rate EU
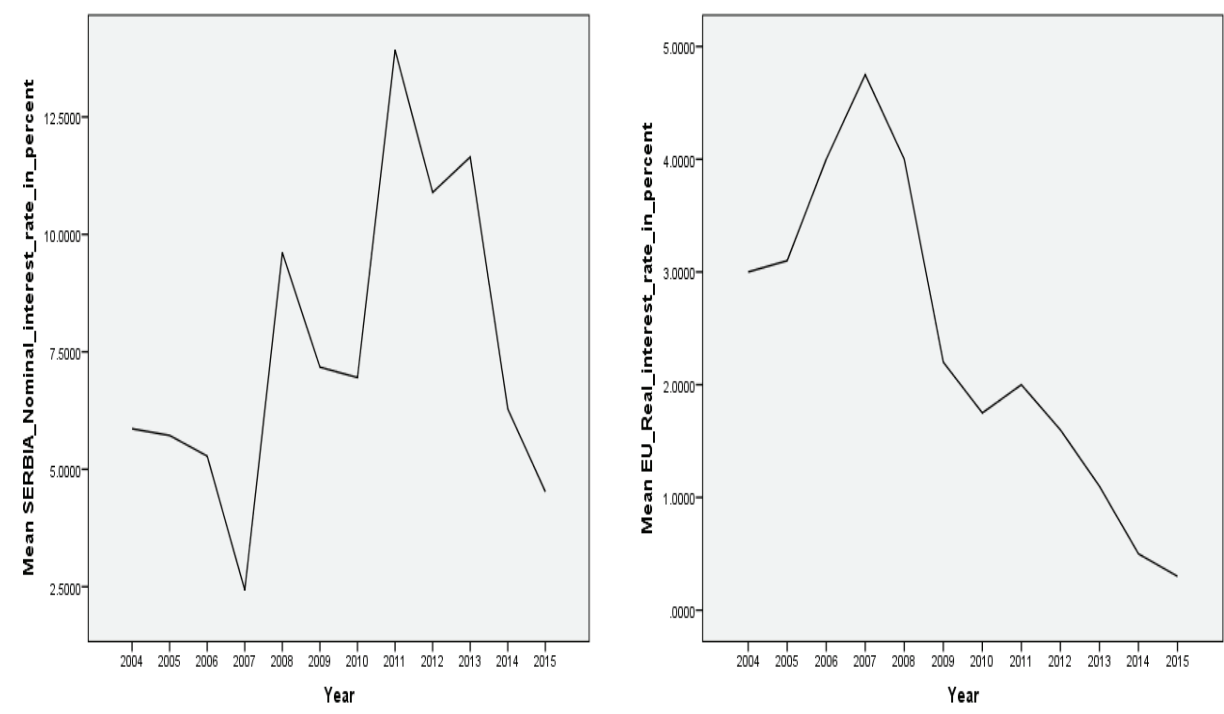

Source (left): Author calculation; Source (right): The European Central Bank

Figure 7 (left): The inflation EU; Figure 8 (right): The nominal interest rate EU
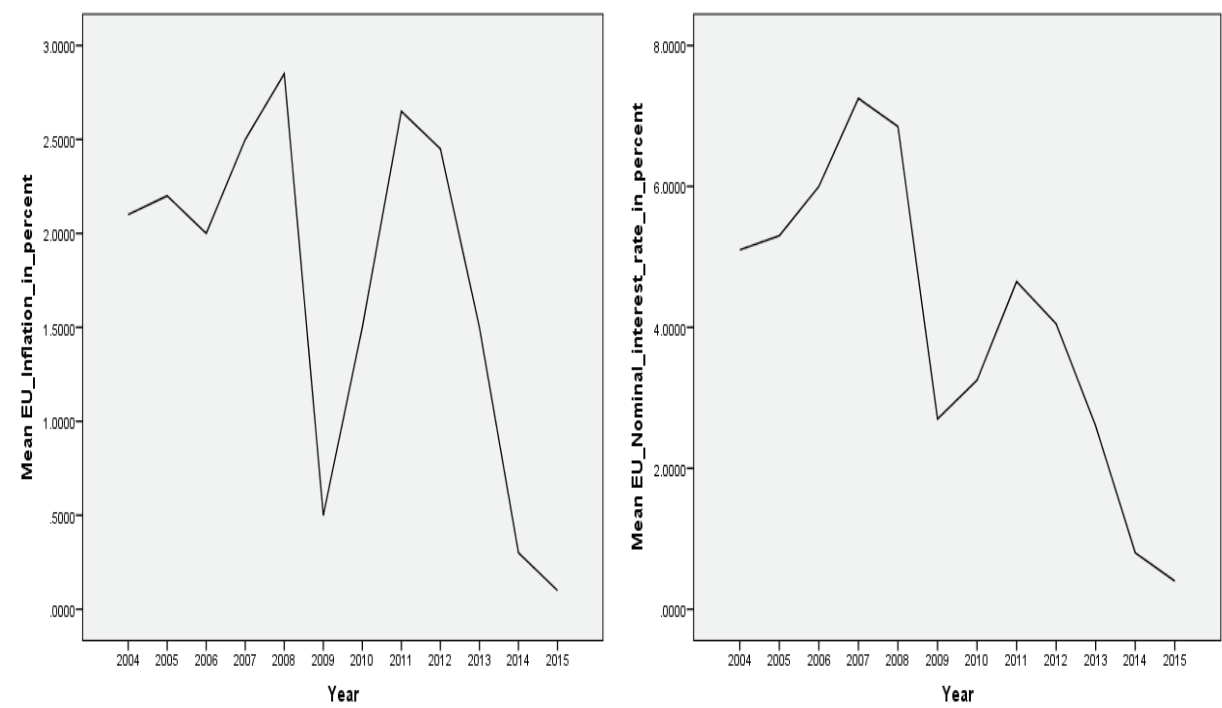

Source (left): The European Central Bank; Source (right): Author calculation 


\section{Results and discussion}

Like we said, linear regression of IFE analysis takes form (7):

$$
\frac{S_{t+1}-S_{t}}{S_{t}}=\alpha+\beta \cdot\left(\frac{r_{n, h, t}-r_{n, f, t}}{1+r_{n, f, t}}\right)+\varepsilon_{t+1}
$$

where $\varepsilon_{t+1}$ is error term.

Testing the parameters of IFE using this regression model is in fact testing the alternative hypothesis $H_{1}$,

$$
H_{1}: \alpha \neq 0 ; \beta \neq 1
$$

against the null hypothesis $H_{0}$,

$$
H_{0}: \alpha=0 ; \beta=1 \text {. }
$$

The alternative hypothesis $H_{1}$

will be accepted if the hypothetical values of $\alpha$ and $\beta,(\alpha=0 ; \beta=1)$, lie outside their respective acceptance regions. In that case we can say that there is no effect of IFE between the observed areas.

The alternative hypothesis $H_{1}$ cannot be accepted if the hypothetical values of $\alpha$ and $\beta,(\alpha=0 ; \beta=1)$, lie within their respective acceptance regions. In that case we cannot say that there is no effect of IFE between the observed areas.

The results of the regression analyzes are given in the following Table 2.

Table 2: IFE regression analysis output

\begin{tabular}{|l|l|r|r|r|r|r|r|}
\hline \multicolumn{1}{|c|}{ Model } & \multicolumn{1}{|c|}{ Value } & $\begin{array}{c}\text { 95\% Confidence } \\
\text { Interval }\end{array}$ & $\boldsymbol{t}$ value & $\boldsymbol{p}$ value & $\mathbf{R}^{2}$ & \multicolumn{1}{c|}{$\begin{array}{c}\text { Durbin- } \\
\text { Watson }\end{array}$} \\
\hline $\begin{array}{l}\text { S e r b i a - } \\
\text { home } \\
\text { EU-foreign }\end{array}$ & Constant $\alpha$ & 0.037 & $(-0.02-0.093)$ & 1.451 & 0.177 & & \\
\hline Coefficient $\beta$ & 0.292 & $(-0.829-1.412)$ & 0.580 & 0.575 & 0.033 & 1.772 \\
$\begin{array}{l}\text { EU-home } \\
\text { S e r b i a - } \\
\text { foreign }\end{array}$ & Constant $\alpha$ & -0.032 & $(-0.082-0.018)$ & -1.433 & 0.182 & & \\
\hline
\end{tabular}

Source: Author calculation

The results obtained in both cases (Serbia-home EU-foreign and EU home Serbia foreign) show:

-the values of $\alpha=0$ and $\beta=1$ are within $95 \%$ confidence interval, so, we cannot say that there is no effect of IFE between Serbia and EU, with the significance level of $5 \%$, respectively $H_{0}$ cannot be rejected in both cases; 
- a $1 \%$ increase in the nominal interest rate differential, on average, lead to approximately a $0.3 \%$ offsetting change in the exchange rate in both cases;

- the coefficients of determination $\mathrm{R}^{2}$ are very low, namely only $3.3 \%$ of the annual changes in the RSD/EUR exchange rate and $4.2 \%$ of the annual changes in the EUR/RSD exchange rate can be explained by the nominal interest differentials. Graphs of regression analyzes are given below (Figure 9., and Figure 10.).

Figure 9 (left): Relative changes of exchange rate RSD/EUR Serbia-home, EU-foreign; Figure 10 (right): Relative changes of exchange rate EUR/RSD

EU-home, Serbia-foreign
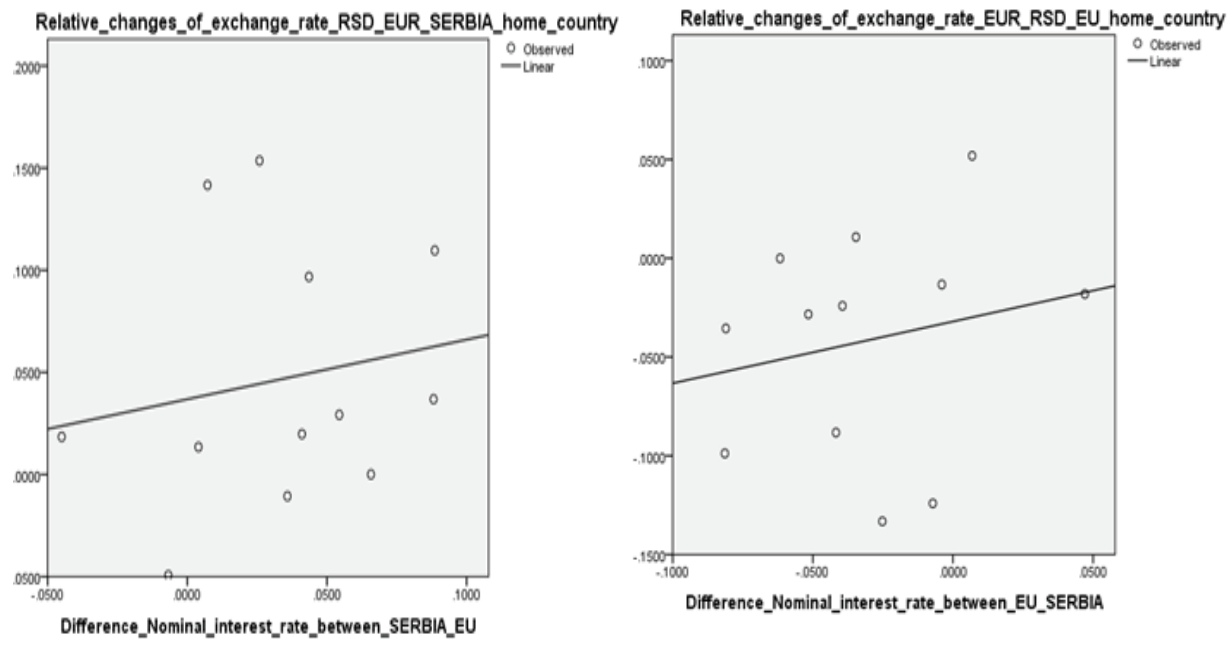

Source: Author calculation

\section{Conclusion}

In this paper we explored International Fisher Effect (IFE) by applying regression analysis between Serbia and European Union. We used historical annual data for exchange rates, real interest rate and inflation for Serbia and EU, in period between 2004 and 2015, and we tested IFE using regression analysis.

Like a home country and foreign country we used each of these countries like interchangeably and track the trail of the effect. Explore was based on the time series of observed data by 2004 to 2015 . We used the data from National bank of Serbia, World Bank and European Central Bank.

Our contribution is reflected in the fact that so far there has been no analysis of the Fisher effect in the observed period between Serbia and the EU. Also, our contribution is the results obtained.

Namely, the results show that a $1 \%$ increase in the nominal interest rate differential, on average, lead to approximately a $0.3 \%$ offsetting change in the exchange rate in both cases (Serbia-home EU-foreign and EU-home Serbia-foreign). 
The coefficients of determination $\mathrm{R}^{2}$ are very low in both cases. Only $3.3 \%$ of the annual changes in the RSD/EUR exchange rate and $4.2 \%$ of the annual changes in the EUR/ RSD exchange rate can be explained by the nominal interest differentials. Therefore, about 96\% of the annual changes in the exchange rates depend on other factors.

\section{References}

Anokye M. A., \& Ofori, D. (2017). Validity of International Fisher Effect in the West African Monetary Zone. Journal of Economic Cooperation \& Development, 38(3), (pp. 121-143).

Bayat, T., Kayhan, S., \& Taşar, İ. (2018). Re-Visiting Fisher Effect for Fragile Five Economies. Journal of Central Banking Theory and Practice, 7(2), (pp. 203-218).

El Khawaga, A., Esam, M., \& Hammam, R. (2013). Exchange Rates and Interest Rates: An Empirical Investigation of International Fisher Effect Theory-The Case of Egypt (2003-2012). International Research Journal of Finance and Economics, 117(2013), (pp. 139-160).

Ercegovac, D., V. Begović, S., \& Jovin, S. (2019): The analysis of the key indicators of the Republic of Serbia banking sector, Vol. 55, No. 41/2019, Journal Annals of the Faculty of Economics in Subotica, pp. 81-94.

European Central Bank, 2019, Retreived August 26, 2019, from https://www.ecb. europa.eu/stats/policy_and_exchange_rates/euro_reference_exchange_rates/ $\mathrm{html} /$ index.en.html

Grujić, B., \& Joksimović, M. (2019). Cooperation of the National Bank of Serbia (NBS) with International Funds and European countries. Chapter 3 in the Book: Serbia: Current Political, Economic and Social Issues and Challenges, Nova Science Publishers, New York, (pp. 43-61).

He, Y. (2018). A Study on the International Fisher Effect: An Investigation from South Korea and China. (IJIDB), 9(7), (pp. 33-42).

Joksimović, M., Grujić, B., \& Joksimović, D. (2018). Correlation and Regression Analysis of The Impact of Leasing on Agricultural Production in Republic of Serbia, Economics of Agriculture 65.2, (pp. 583-600).

Kaludjerovic, N., Stanojevic, S., \& Ljubic, M. (2016). Hidden Losses in Financial Reporting and the Manner of Hiding Case Serbia - Part Two. International review (Faculty of Business Economics and Entrepreneurship), No. 1/2, (pp. 125-141).

Korab, P., \& Svatopluk, K. (2013). International fisher effect under exchange rate regime shifts: Evidence from 10 examples, Society and Economy 35(4), (pp. 451-469).

Madura, J. (2010). International Financial Management, 10th Edition, South-Western, College Publishing.

Machobani, D., Boako, G., \& Alagidede, P. (2017). Uncovered Interest Parity, Purchasing Power Parity and the Fisher effect: Evidence from South Africa. Frontiers in Finance and Economics, 14(2), (pp. 88-134). 
Muhović, A., \& Subić, J. (2019). Analysis and impact of main macro and microeconomic factors on the growth of NPL-S in the emerging financial markets. Journal Ekonomika, No. 4, Society of Economists "Ekonomika", Nis, (pp. 21-30).

Nchor, D., \& Darkwah, S. A. (2015). Inflation, exchange rates and interest rates in Ghana: An autoregressive distributed lag model. Acta Universitatis Agriculturae et Silviculturae Mendelianae Brunensis, 63(3), (pp. 969-977).

National Bank of Serbia, 2018, Average exchange rates of the RSD against the world's leading currencies, Retreived August 25, 2019, from http:/www.nbs.rs/internet/ english/scripts/kl_prosecni.html

Shalishali, Maurice K. (2012). A test of the international fisher effect in selected Asian countries. International Journal of Humanities and Social Science, 2(4), (pp. 8692).

The World Bank, 2019, Retrieved August 20, 2019, from https://data.worldbank.org/ indicator/FP.CPI.TOTL.ZG?locations $=$ RS\&view $=$ chart

Ucak, H., Ozturk, I., \& Aslan, A. (2014). An Examination of Fisher Effect for Selected New EU Member States. International Journal of Economics and Financial Issues, 4(4), (pp. 956-959).

Uyaebo, S. O., Bello, Y. A., Omotosho, B. S., Karu, S., Stephen, S. A., Ogbuka, R. O., ... \& Mimiko, O. D. (2016). Testing the Fisher hypothesis in the presence of structural breaks and adaptive inflationary expectations: Evidence from Nigeria. CBN Journal of Applied Statistics, 7(1), (pp. 333-358).

Varamini, H., Clough, J., \& McCall, M. (2017). An Empirical Investigation of the International Fisher Effect: Mexican Peso and United States Dollar. International Journal of Economics and Financial Research, 3(7), (pp. 110-113). 